\title{
LCA における配分問題に対する一考察
}

\author{
中西英二・磯部靖三・高松武一郎 \\ 関西大学工学部化学工学科 ${ }^{\dagger+}$
}

\section{安岡弘陽}

神戸大学工学部 応用化学科 ${ }^{+\dagger}$

\section{伊東速水}

\author{
川崎重工業(株)明石技術研究所 ${ }^{\dagger+\dagger}$
}

\begin{abstract}
LCA において未解決の問題として残されている配分問題に対して $\phi$ 収支の考えを導入 することにより, 地球環境問題のような大規模システムにおける累積環境影響負荷を算出 するアルゴリズムを提案した：これをべースとして，対象とするシステムのフローシート を炎のままインベントリ表に写し, 光れを自動的に読み込んで累積環境影響負荷を算出す るプログラムを併せて開発した。これを用いて, ユニットにおけるアウトプットの重量あ たり同一配分, 燃焼熱比による配分, 価格比におよる配分の 3 つのケースについてプラス チック原料の累積 $\mathrm{CO}_{2}$ 原単位の算出を試み, 本論文で提唱したアルゴリズムの適用性, 光 のコンピュータプログラムの実用性を検証した.
\end{abstract}

\section{緒言}

Fig. 1 に示すようないくつかのサブシステム（以下ュ ニット）で構成されるトータルステムに対して環境影響 評価を論ずる場合，環境影響負荷に関して各ユニット間 ならびにユニットとシステムバウンダリを出入りするイ ンプット，アウトプットとの間の因果関係がまず必要と なる。環境影響負荷が $\mathrm{CO}_{2}$ のような物質の場合 $\mathrm{CO}_{2}$ 収 支より, 熱污染の場合には熱収支より因果関係が決まる. ユニットの出力が 1 つ場合, このような物質収支ある いは熱収支を全てのユニットに適用して，トータルシス テムの入力を初期条件として各ユニットの出力及びアウ トプットが解き出せ, トータルシステムの環境影響評価 が数值的に導き出せる.しかしながらユニットで 2 つ以 上の出力を有するものが存在する場合, そのようなユ二

\footnotetext{
$\dagger 1995$ 年 10 月 26 日受理

†† 564 吹田市山手町 3-3-35

什 $\overline{7} 657$ 神戸市灘区六甲台町 1-1

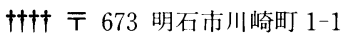

ットについては出力間の関係を別途与えないと解を導き 出せない. この問題は, 地球環境問題の環境影響評価法 に関する LCA (Life Cycle Assessment) において配分 問題 (allocation or partitioning problem) と称せられ 今なお澥決の重要課題の1つとして残されている. 本 論文ではいかなる配分の基準に対しても対応できるよう な算出法を提案し，それをベースにしてLCA コンピュ 一タプログラムを作成し, 石油化学製品の基礎原料製造 プロセスにおける $\mathrm{CO}_{2}$ 負荷算出に適用してその実用性 を検証した。

\section{1. 累積環境影響負荷と配分係数}

物質なりエネルギーが天然資源の状態から現在ある状 態に至るまでに放出してきた環境影響負荷の累積值を累 積環境影響負荷と定義する，以下においては環境影響負 荷が $\mathrm{CO}_{2}$ の場合について論議を進めるが同じことが他 の環境影響負荷についても適用でき一般性を失わない. 物質 $1 \mathrm{t}$ あるいはエネルギー $1 \mathrm{kWh}$ 得るのに天然資源 の状態から現在ある状態に至るまでに放出してきた $\mathrm{CO}_{2}$ の累積值を $\phi$ で表わし,これを累積 $\mathrm{CO}_{2}$ 排出原単位と定 


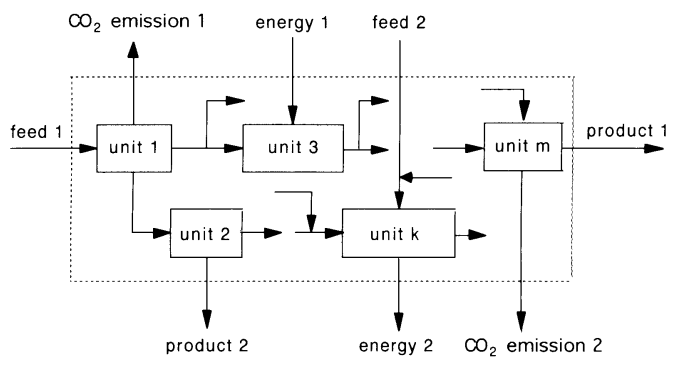

Fig. 1 Configuration of total system, subsystems and system boundary

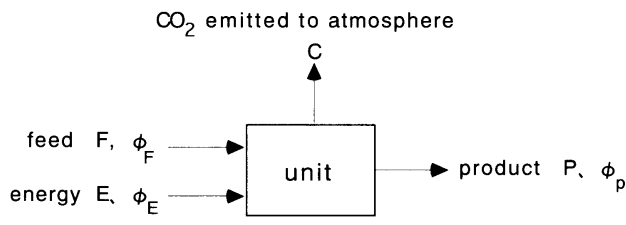

Fig. 2 Double inputs-single output system emitting $\mathrm{CO}_{2}$ to atmosphere

義し, その単位は物質に関して $\mathrm{kgCO}_{2} / \mathrm{t}$, エネルギーに 関して $\mathrm{kgCO}_{2} / \mathrm{kWh}$ である。

Fig. 2 に示すユニットでいわゆる積み上げ方式による 累積 $\mathrm{CO}_{2}$ に関して, $\mathrm{CO}_{2}$ 収支より次式が成立することは 明らかである。

$$
P \phi_{P}=F \phi_{F}+E \phi_{E}+C
$$

ユニットからの出力が 2 つの以上の場合は Eq. (1) の $\mathrm{CO}_{2}$ 収支のみからは累積 $\mathrm{CO}_{2}$ の関係は決まらない. 説明 を簡単にするために Fig. 3 のユニットについて考える. このユニットにおける $\mathrm{CO}_{2}$ 収支より

$$
P_{1} \phi_{1}+P_{2} \phi_{2}=F \phi_{F}
$$

$\phi_{1} ， \phi_{2}$ を決定するためには Eq. (2) だけでは不十分で $\phi_{1}, \phi_{2}$ に関する他の条件が必要である。この条件が環境 影響評価に際しての配分問題と称せられるもので， $\phi_{1}$, $\phi_{2}$ に対してどのように累積 $\mathrm{CO}_{2}$ 排出原単位を割り当て るのが合理的かについては議論のあるところで，製品の 価格比やそれが石油化学製品の場合燃焼熱比に応じて $\phi_{1}, \phi_{2}$ を割り当てるなどが提案されているが(Boustead, 1992）今のところ確定した答えは出されていない.

本論文では $\phi_{1}, \phi_{2}$ に関する条件として次の関係を採 用した。

$$
\phi_{1}: \phi_{2}=\alpha_{1}: \alpha_{2}
$$

ここで $\alpha_{1}, \alpha_{2}$ は任意パラメータで, これまで提案されて いる出力 $\phi$ の同一比, エネルギー比, 価格比いずれにも 対応できる. Eqs. (2)，(3) より

$$
\begin{aligned}
& \phi_{1}=\alpha_{1} F \phi_{F} /\left(\alpha_{1} P_{1}+\alpha_{2} P_{2}\right) \\
& \phi_{2}=\alpha_{2} F \phi_{F} /\left(\alpha_{1} P_{1}+\alpha_{2} P_{2}\right)
\end{aligned}
$$

一方，Fig. 4 に示すュニットの $\mathrm{CO}_{2}$ 収支 (これを $\phi$ 収

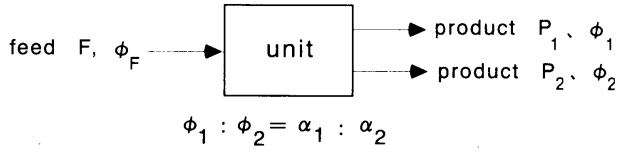

Fig. $3 \mathrm{CO}_{2}$ balance in a single input-double outputs system

feed

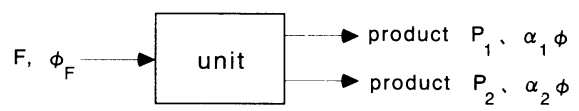

Fig. $4 \phi$ balance in a single input-double outputs system

$$
\begin{gathered}
\text { 支と呼ぶことにする）を考えると } \\
\alpha_{1} P_{1} \phi+\alpha_{2} P_{2} \phi=F \phi_{F} \\
\text { したがって } \\
\quad \phi=F \phi_{F} /\left(\alpha_{1} P_{1}+\alpha_{2} P_{2}\right)
\end{gathered}
$$

すなわち Eq. (5) で関係づけられる 式の $\phi_{1}, \phi_{2}$ は次式よっても得られることは明らかであ る.

$$
\phi_{1}=\alpha_{1} \phi, \quad \phi_{2}=\alpha_{2} \phi
$$

以上のことより Fig. 3 と Fig. 4 のユニットは Eq. (7) の介在を通して等価であることが云えた。しかしながら Fig. 3 による場合は $\phi_{1}, \phi_{2}$ の 2 変数を解くのに対して, Fig. 4 による場合は $\phi$ の 1 変数を解けばよいという点 に大きな差異がある. Fig. 3 でユニットの出力数が一般 に $f$ の場合, Fig. 3 による場合は $\phi_{i}(i=1,2, \cdots, f)$ の $f$ 変数について解くのに対して，Fig. 4 による場合は依然 として $\phi$ の 1 変数を解けばよいという点でその差異は 歴然で, Fig. 1 で各ユニットが多くの出力を有する一般 のケースでは Fig. 4 の $\phi$ 収支に基づく解析が Fig. 3 の $\mathrm{CO}_{2}$ 収支に基づく解析に比して断然優位となることは 明らかである。これにより，次節で $\mathrm{Eq}(4)$ の $\mathrm{CO}_{2}$ 収支の 代わりに $\mathrm{Eq}(5)$ の $\phi$ 収支と $\mathrm{Eq}(7)$ の関係を用いて，各 ユニットでの累積 $\mathrm{CO}_{2}$ 排出原単位を算出するための行 列計算量が格段に節減される.

\section{2. ユニットおよびアウトプットにおける $\phi$ 収支}

Fig. 5 は $m$ 個のユニットからなるトータルシステム のシステムバウンダリを通して， $n$ 個のマテリアルイン プット及び $s$ 個のエネルギーインプットと $r$ 個のアウ トプットが入出している様子を表わしている.この図に おいて, $y$ は物質あるいはエネルギーの流量, $\alpha, \phi$ は各 ユニットでの配分係数, 累積 $\mathrm{CO}_{2}$ 排出原単位で記号の詳 細は下記に示す.

$y_{U i w, U j}$ : ユニット $U_{i}$ から産出される $w$ 番目の 物質でユニット $U_{j}$ への供給量

$y_{\text {Uiw,og }}$ : ユニット Ui から産出される $w$ 番目の 


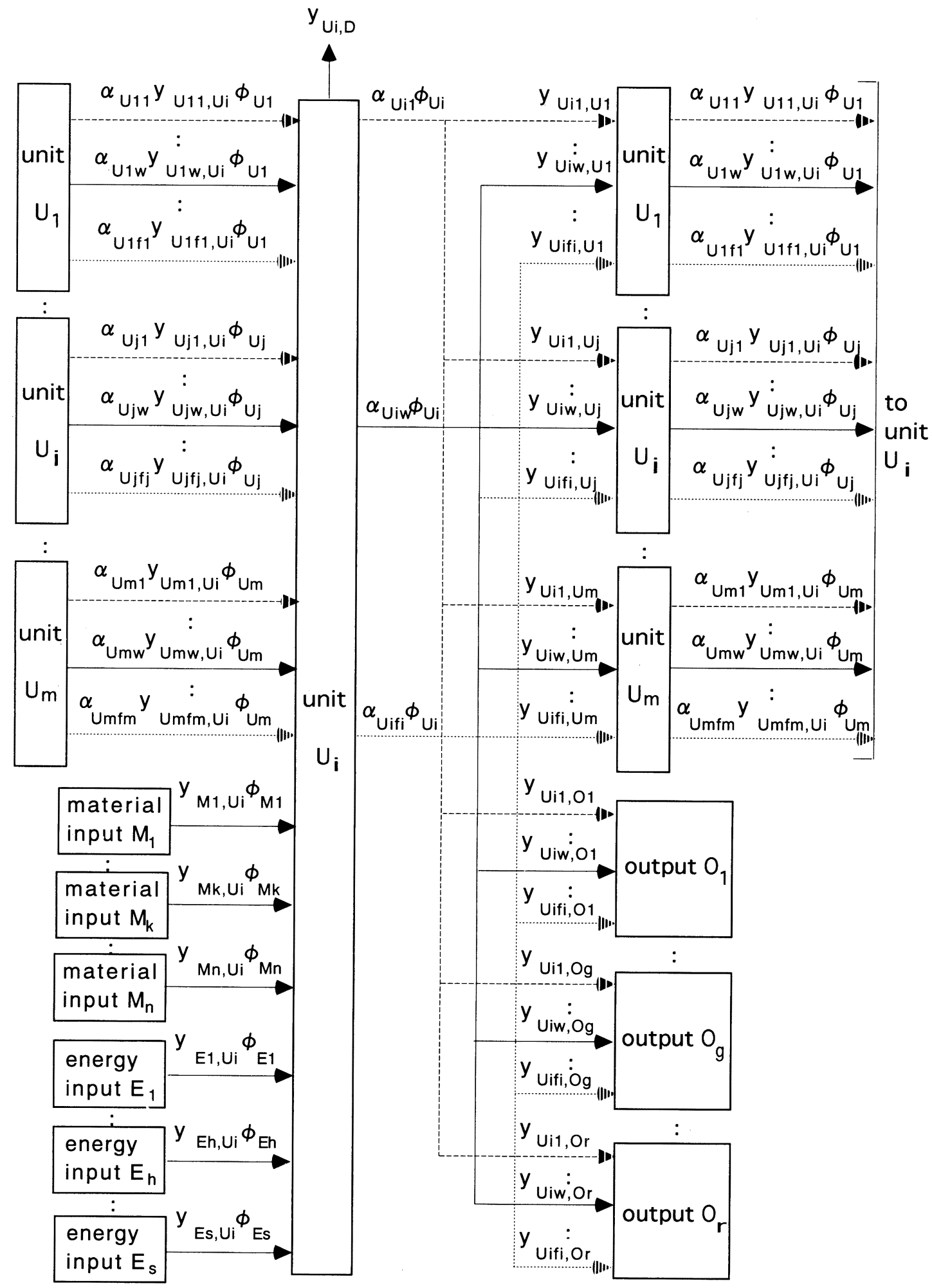

Fig. $5 \phi$ balance in the unit $U_{i}$ 
物質でアウトプット $O_{g}$ への供給量

$y_{M k, U j}$ : マテリアルインプット $M_{k}$ からユニッ

ト $U_{j}$ に供給される物質量

$y_{M k, O g}$ : マテリアルインプット $M_{k}$ からアウト プット $O_{g}$ に供給される物質量

$y_{E h, U j} \quad:$ エネルギーインプット $E_{h}$ からユニッ

ト $U_{j}$ に供給されるエネルギー量

$y_{E h, O g}:$ エネルギーインプット $E_{h}$ からアウト プット $O_{g}$ に供給されるエネルギー量

$y_{U i, D} \quad:$ ユニット $\mathrm{Ui}$ からの $\mathrm{CO}_{2}$ 排出量

$\alpha_{U i w} \quad$ : ユニット $U_{i}$ から産出される $w$ 番目の 物質に対する配分係数

Eq. (5)にしたがってユニット $U_{i}(i=1,2, \cdots, m)$ にお ける $\phi$ 収支式は次式で表わされる。

$$
\begin{aligned}
& y_{M 1, U i} \phi_{M 1}+\cdots+y_{M, U i} \phi_{M n}+y_{E 1, U i} \phi_{E 1}+\cdots \\
& \quad+y_{E s, U i} \phi_{E s}-y_{U i, D} \phi_{D}+\left(\alpha_{U 11} y_{U 11, U i}+\cdots\right. \\
& \left.+\alpha_{U 1 f 1} y_{U 1 f 1, U i}\right) \phi_{U 1}+\cdots \\
& \quad\left(\alpha_{U m 1} y_{U m 1, U i}+\cdots+\alpha_{U m f m} y_{U m f m, U i}\right) \phi_{U m}=\phi_{U i} x_{U i} \\
& x_{U i}=\alpha_{U i 1}\left(y_{U i 1, U 1}+\cdots+y_{U i 1, U m}+y_{U i 1, O 1}+\cdots\right. \\
& \left.+y_{U i 1, O r}\right)+\cdots \alpha_{U i f i}\left(y_{U i f i, U 1}+\cdots+y_{U i f i, U m}\right. \\
& \left.+y_{U i f i, o 1}+\cdots+y_{U i f i, o r}\right)
\end{aligned}
$$

一方 Fig. 6 に示されるアウトプット $O_{g}(g=1,2, \cdots$, $r)$ に対する $\phi$ 収支式は

$$
\begin{aligned}
& \left(\alpha_{U 11} y_{11, o g}+\cdots+\alpha_{U 1 f 1} y_{U 1 f 1, o g}\right) \alpha_{U 1}+\cdots \\
& \quad+\left(\alpha_{U m 1} y_{U m 1, o g}+\cdots+\alpha_{U m f m, o g}\right) \phi_{U m}= \\
& x_{o g}=\left(y_{U 11, o g}+\cdots+y_{U 1 f 1, o g}\right)+\cdots \\
& \quad+\left(y_{U m 1, o g}+\cdots+y_{U m f m, o g}\right)
\end{aligned}
$$$$
+\left(\alpha_{U m 1} y_{U m 1, o g}+\cdots+\alpha_{U m f m, o g}\right) \phi_{U m}=\phi_{o g c} x_{o g}
$$

Eqs. (8)，（9），(10）を合体して次式が得られる.

$$
\boldsymbol{Y}_{M} \phi_{M}+\boldsymbol{Y}_{E} \phi_{E}+\boldsymbol{S} \phi-\boldsymbol{Y}_{D} \phi_{D}=\boldsymbol{X} \phi
$$
ただし

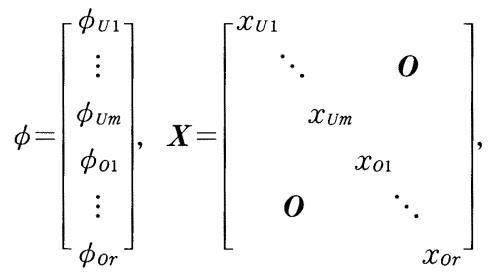

$$
\begin{aligned}
& \boldsymbol{B}^{\mathrm{T}}=\left[\begin{array}{ccc}
y_{M 1, U 1} & \cdots & y_{M n, U 1} \\
\vdots & \cdots & \vdots \\
y_{M 1, U m} & \cdots & y_{M n, U m}
\end{array}\right], \quad C^{\mathrm{T}}=\left[\begin{array}{ccc}
y_{E 1, U 1} & \cdots & y_{E s, U 1} \\
\vdots & \cdots & \vdots \\
y_{E 1, U m} & \cdots & y_{E s, U m}
\end{array}\right] \\
& \boldsymbol{Y}_{M}=\left[\begin{array}{c}
\boldsymbol{B}^{\mathrm{T}} \\
\boldsymbol{O}_{2}
\end{array}\right], \quad \boldsymbol{Y}_{E}=\left[\begin{array}{c}
\boldsymbol{C}^{\mathrm{T}} \\
\boldsymbol{O}_{3}
\end{array}\right], \quad \boldsymbol{Y}_{D}=\left[\begin{array}{c}
y_{U 1, D} \\
\vdots \\
y_{U m, D} \\
\boldsymbol{O}_{4}
\end{array}\right]
\end{aligned}
$$

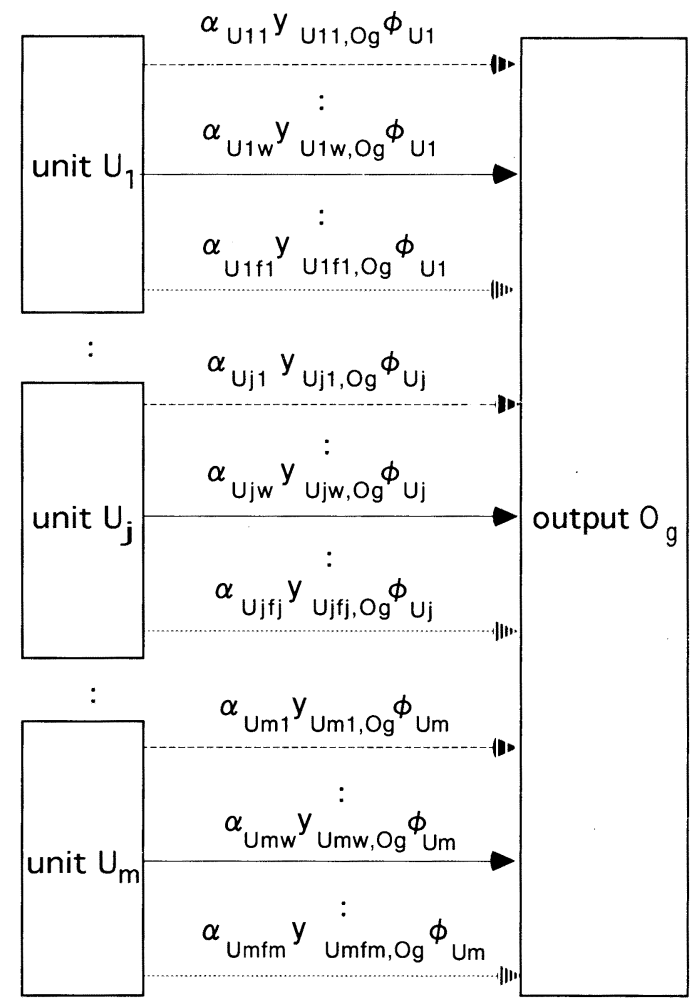

Fig. $6 \phi$ balance in the output $O_{g}$

$$
\begin{aligned}
& \phi_{M}=\left[\begin{array}{c}
\phi_{M 1} \\
\vdots \\
\phi_{M n}
\end{array}\right], \quad \phi_{E}=\left[\begin{array}{c}
\phi_{E 1} \\
\vdots \\
\phi_{E S}
\end{array}\right], \\
& \boldsymbol{O}_{1}=\boldsymbol{O}_{(m+r) \times r}, \quad \boldsymbol{O}_{2}=\boldsymbol{O}_{r \times n}, \quad \boldsymbol{O}_{3}=\boldsymbol{O}_{r \times s}, \quad \boldsymbol{O}_{4}=\boldsymbol{O}_{r \times 1}
\end{aligned}
$$

$$
\begin{aligned}
& \alpha_{U i}=\left[\begin{array}{c}
\alpha_{U i 1} \\
\vdots \\
\alpha_{U i f i}
\end{array}\right], \boldsymbol{A}_{i}{ }^{\mathrm{T}}=\left[\begin{array}{ccc}
y_{U i 1, U 1} & \cdots & y_{U i f i, U 1} \\
\vdots & \cdots & \vdots \\
y_{U i 1, U m} & \cdots & y_{U i f i, U m} \\
y_{U i 1, o 1} & \cdots & y_{U i f i, O 1} \\
\vdots & \cdots & \vdots \\
y_{U i 1, o r} & \cdots & y_{U i f i, o r}
\end{array}\right], \\
& R_{i}=A_{i}{ }^{\mathrm{T}} \alpha_{U i}(i=1,2, \cdots, m), \\
& \boldsymbol{S}=\left[R_{1}, R_{2}, \cdots, R_{m}, O_{1}\right]
\end{aligned}
$$

Eq. (11) を整理して

$$
(\boldsymbol{S}-\boldsymbol{X}) \phi=-\boldsymbol{Y}_{M} \phi_{M}-\boldsymbol{Y}_{E} \phi_{E}+\boldsymbol{Y}_{D} \phi_{D}
$$

すなわち

$$
\phi=-(\boldsymbol{S}-\boldsymbol{X})^{-1}\left(\boldsymbol{Y}_{M} \phi_{M}+\boldsymbol{Y}_{E} \phi_{E}-\boldsymbol{Y}_{D} \phi_{D}\right)
$$

最終的に Eq. (12) により各ユニット及びアウトプット の $\phi$ が算出される.

\section{3. プラスチック原料の累積 $\mathrm{CO}_{2}$ 排出原単位の算出}

対象とするシステムのフローシートを描き, システム バウンダリを通過するインプット及びアウトプット，各 
U1
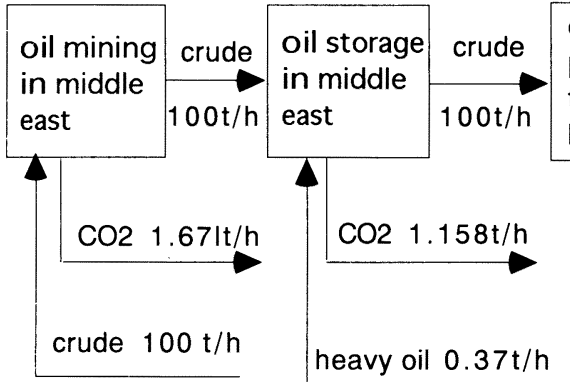

U3

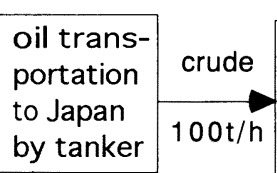

$\Delta$

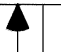

$\mathrm{CO} 25.076 \mathrm{t} / \mathrm{h}$

heavy oil $1.62 t / h$
U4

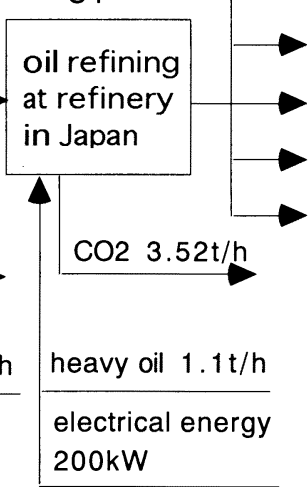

naphtha $12.1 \mathrm{t} / \mathrm{h}$

01 : IPG $\mathrm{O} 2$ : light oil $13.2 \mathrm{t} / \mathrm{h}$

O3 : kerosene $15.3 \mathrm{t} / \mathrm{h}$ O4 : heavy oil $58.7 \mathrm{t} / \mathrm{h}$ recycling to

U2: $0.37 \mathrm{t} / \mathrm{h}$

U3 : $1.62 \mathrm{t} / \mathrm{h}$

U4: $1.10 \mathrm{t} / \mathrm{h}$

U5: $1.61 \mathrm{t} / \mathrm{h}$

U6: $0.168 \mathrm{t} / \mathrm{h}$

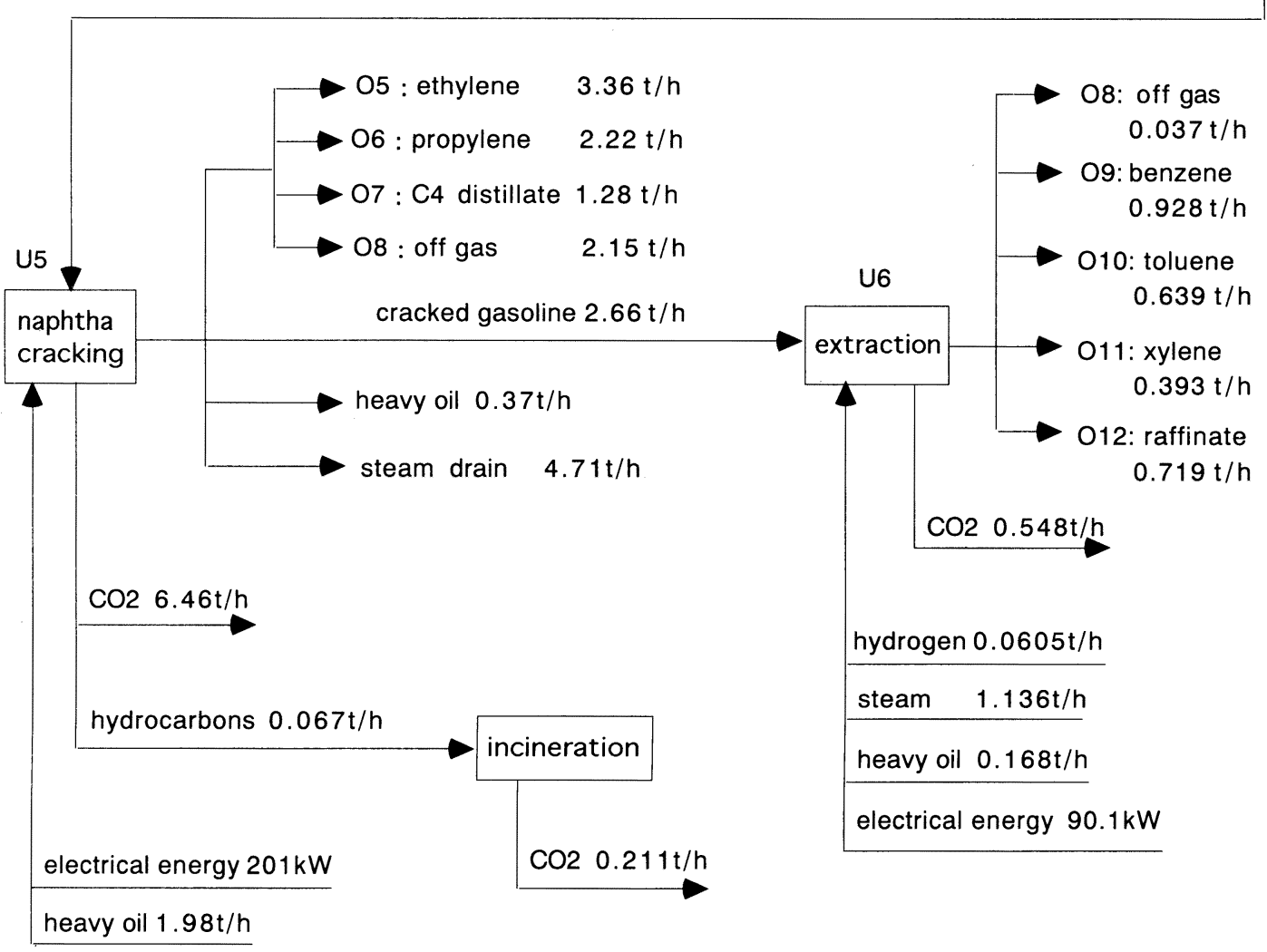

Fig. 7 Crude distillation/naphtha cracking process

ユニットに出入りする物質量, エネルギー量及びそこで 発生する $\mathrm{CO}_{2}$ 量を Table 1 に示すインベントリ表に記 入する.このインベントリ表は平面上に描かれたフロー シートと直接的に対応して作成される. Excelのワーク シート上に Table 1 のインベントリ表を作成し，そこか ら読み込まれたデータから自動的に Eq. (12) を計算す るソフトを開発し, Fig. 7 に示す工程（NEDO-RITE-
SCEJ，1995）に対して産油地での天然資源としての原油 の累積 $\mathrm{CO}_{2}$ 排出原単位=0 を初期值として各ユニットで 生成される石油化学原料の累積 $\mathrm{CO}_{2}$ 排出原単位を算出 し Table 2 に示す結果を得た。ここで $\phi_{W}, \phi_{E}, \phi_{P}$ は製 品の重量当たり同一配分, 製品の燃焼熱比による配分, 製品の価格比による配分である。 
Table 1 Inventory table

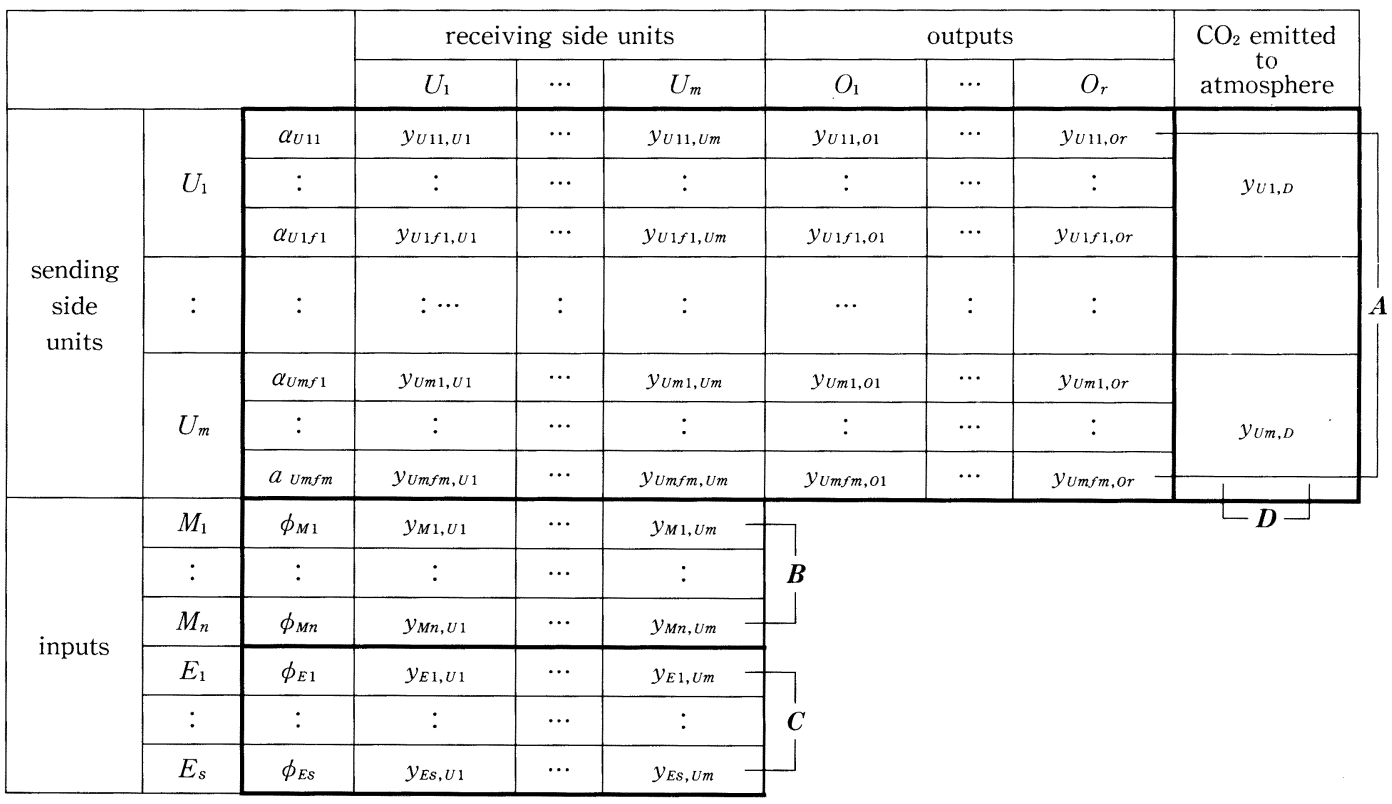

Table 2 Calculated $\boldsymbol{\phi}$ of hydrocarbons based on three kinds of partitioning (suffixes $W, E, P$ denote weight, energy and price bases, respectively)

\begin{tabular}{|c|c|c|c|c|c|c|}
\hline processes & products & $\begin{array}{l}\text { price } \\
(¥ / \mathrm{kg})\end{array}$ & $\begin{array}{l}\text { heat of combustion } \\
(\mathrm{MJ} / \mathrm{kg})\end{array}$ & $\begin{array}{c}\phi_{W} \\
\left(\mathrm{~kg}-\mathrm{CO}_{2} / \mathrm{t}\right)\end{array}$ & $\begin{array}{c}\phi_{E} \\
\left(\mathrm{~kg}-\mathrm{CO}_{2} / \mathrm{t}\right) \\
\end{array}$ & $\begin{array}{c}\phi_{P} \\
\left(\mathrm{~kg}-\mathrm{CO}_{2} / \mathrm{t}\right)\end{array}$ \\
\hline crude distillation & $\begin{array}{l}\text { nuphtha } \\
\text { LPG } \\
\text { light oil } \\
\text { kerosene } \\
\text { heavy oil }\end{array}$ & $\begin{array}{l}28.80 \\
25.60 \\
31.80 \\
30.70 \\
27.80\end{array}$ & $\begin{array}{l}47.98 \\
50.34 \\
47.35 \\
47.56 \\
47.23\end{array}$ & 119 & $\begin{array}{l}120 \\
126 \\
119 \\
119 \\
119\end{array}$ & $\begin{array}{l}119 \\
105 \\
131 \\
126 \\
115\end{array}$ \\
\hline \multirow{3}{*}{ naphtha cracking } & $\begin{array}{c}\text { ethylene } \\
\text { propylene } \\
\text { C4 distillate } \\
\text { cracked gasoline }\end{array}$ & $\begin{array}{r}103.00 \\
83.00 \\
64.60 \\
65.40\end{array}$ & $\begin{array}{l}51.47 \\
49.00 \\
48.52 \\
47.98\end{array}$ & 710 & $\begin{array}{l}726 \\
689 \\
682 \\
677 \\
\end{array}$ & $\begin{array}{l}987 \\
795 \\
619 \\
625\end{array}$ \\
\hline & $\begin{array}{l}\text { benzene } \\
\text { toluene } \\
\text { xylene } \\
\text { raffinate }\end{array}$ & $\begin{array}{l}75.00 \\
86.00 \\
84.00 \\
64.60\end{array}$ & $\begin{array}{l}41.89 \\
42.50 \\
42.95 \\
46.12\end{array}$ & 1038 & $\begin{array}{r}966 \\
980 \\
988 \\
1063\end{array}$ & $\begin{array}{r}947 \\
1086 \\
1058 \\
816\end{array}$ \\
\hline & offgas & 36.00 & 55.64 & 716 & 791 & 347 \\
\hline
\end{tabular}

\section{おわりに}

ユニット出力に対する配分法として，製品の重量当た り同一配分, 製品の燃焼熱比による配分, 製品の価格比 による配分の 3 つの場合について累積 $\mathrm{CO}_{2}$ 排出原単位 の算出を行ったが，始めにも述べたように現在のところ いずれの配分による算出が合理的かについてはコンセン サスは得られていない. しかしながらいずれの配分によ るにしろ本論文で提案した算出法でLCAにおけるいわ ゆる配分問題に対して柔軟に対応できることが明らかと
なった。

[謝辞] 本研究を進めるに当たり費用の一部は（社）化学 工学会が (財) 地球環境産業技術研究機構より委託された地球環 境プロジェクト研究費によった。ここに両法人に謝意を表するも のである。

\section{Nomenclature}

$C=\mathrm{CO}_{2}$ emission rate

$E=$ energy rate 


$$
\begin{array}{rrr}
F & =\text { feed rate } & {[\mathrm{t} / \mathrm{h}]} \\
P & =\text { product rate } & {[\mathrm{t} / \mathrm{h}]} \\
y & =\text { material or energy rate in a unit }[\mathrm{t} / \mathrm{h}], & {[\mathrm{kW}]} \\
\alpha & =\text { partitioning coefficient } & {[-]} \\
\phi & =\text { cumulative } \mathrm{CO}_{2} \text { emission unit } &
\end{array}
$$

$[\mathrm{kg} / \mathrm{t}], \quad[\mathrm{kg} / \mathrm{kWh}]$

\section{Literature cited}

Boustead, I. : Ecobalance Methodology for Commodity Thermoplastics, A Report for the European Centre for Plastics in the Environment (1992)

NEDO-RITE-SCEJ : Study of the Analytical Method of Total Ecobalance for Industrial Chemical Products (II), NEDO-GET 9410-1 (1995)

\title{
A Study of Partitioning Problem in Life Cycle Assessment
}

\author{
Eiji Nakanishi, Seizou Isobe and Takeichiro Takamatsu \\ Dept. of Chem. Eng., Kansai Univ., Suita 564
}

\section{Hiroaki Yasuoka}

Dept. of Chem. Sci. and Eng., Kobe Univ., Kobe 657

\section{Hayami Itoh}

Akashi Tech. Inst., Kawasaki Heavy Industries, Ltd., Akashi 673

\begin{abstract}
Key Words: Life cycle assessment, $\mathrm{CO}_{2}$, emission system, Environment protection technology, Evaluation of enviroment pollutions, Allocation or partitioning problem, LCA computer program
\end{abstract}

The so-called allocation or partitioning problem which is still indeterminable in life cycle assessment (LCA) has been studied. The $\phi$ balance defined in this study is used to describe the relations of inputs and outputs in each subsystem consisting of the whole environment system. In doing so, the mass balance of pollutant materials in environment system under consideration is expressed in much smaller dimension compared to the case where the conventional mass balance is employed and thus the mathematical procedure is highly simplified in establishing a computer program for calculating the cumulative $\mathrm{CO}_{2}$ emission unit which is equivalent to the total quantity of $\mathrm{CO}_{2}$ emitted to the atmosphere to produce the present material or energy from raw fossil resources. The cumulative $\mathrm{CO}_{2}$ emission unit which is an indicative value of $\mathrm{CO}$ 2 pollution used in this study of LCA are calculated for some petrochemical materials for plastics depending on several kinds of partitionings. 